\title{
An Analysis of the Effectiveness of Allocation of Village Fund Policy Implementation and Its Determining Factors in Gorontalo Regency
}

\author{
Ismet Sulila \\ Department of Public Administration, Faculty of Economics, Universitas Negeri Gorontalo \\ Email: ismet.sulila@gmail.com
}

(Received: November 11-2019; revised: December 1-2019; published: December 31-2019)

\begin{abstract}
This study aims at examining the realization of the allocation of village fund, income per capita, and what factors determine the effectiveness of the implementation of village fund allocation policies in Gorontalo District. The complexity of implementing village fund policies requires caution in empirical studies in the field. Therefore the research approach uses qualitative methods. The data source in this study was primary data, which was conducted using a matrix of problem-based interview guidelines. Further, the data analysis techniques used consisted of data collection, data display, data condensation and verifying drawing conclusions. Data obtained in the field show that the allocation of village fund continues to increase. The impact of an increase in the allocation of village fund to the level of development in the village can be seen through per capita income in the last five years that has increased. Furthermore, the results of empirical studies in the field show that there are five important factors that determine the effectiveness of the implementation of village fund policies in Gorontalo District, namely 1) Participation, 2) communication, 3) resources, 4) attitude of implementers 5) organizational structure of implementers, 6) environment.
\end{abstract}

Keywords: Effectiveness, Policy, Allocation of Village Fund

\section{INTRODUCTION}

Law of the Republic of Indonesia Number 6 of 2014 concerning Villages is a product of the reform era, which became the initial form of village independence in the administration of Government and in the management of Village Finances. The village occupies a very important position in the national development process because it is the smallest government structure and comes into direct contact with the community. For this reason, according to Abidin (2015) the government and the DPR have a strong commitment by issuing a government policy on villages. Villages that were once only used as objects of development now have a very important role in national development. One of the government's strategies to make villages independent is to provide allocation of village fund. Allocation of Village fund sourced from the state income and expenditure budget which are intended for villages that are transferred through the regency/city regional income and expenditure budget and are used to finance governance, development implementation, community development, and community empowerment (Nawir, Maulana, Nuryamin, \& Husain, 2018; Syamsiar, Saggaf, Salam, \& Ihsan, 2018).

In the implementation of the fund received by the Village, the amount is quite large and continues to increase every year, so in organizing Government and Village Financial Management, it needs a capacity of Village Apparatus that is reliable and other adequate facilities so that its implementation becomes more directed and accountable. The Allocation of Village Fund is a form of financial relations between levels of government, namely the financial 
192 Jurnal Ilmiah Ilmu Administrasi Publik: Jurnal Pemikiran dan Penelitian Administrasi Publik

Volume 9 Number 2,July - December 2019. Page 191-202

relationship between the Regency Government and the Village Government. To be able to formulate an appropriate financial relationship, an understanding of the authority of the village government is needed. This means that the government budget given to the village is fully related to development facilities and village empowerment as one of the institutions that contribute to the governance format. These fund must be used and allocated as appropriate in accordance with applicable laws and regulations set by the government.

Village development has been one of the topics that have always been discussed in the discussion of the practice of regional autonomy in Indonesia. Yet according to Hehamahua (2015), the main goal of development is to increase the distribution of development and other programs in rural areas. That is, rural areas are the subject of development, which rests on the paradigm that the essence of regional autonomy is to realize regional independence through strengthening local potential. According to Prasetyo \& Masdjojo (2015), in the framework of village autonomy, all forms of village government affairs become village authority, including in terms of village financial management. The allocation of village fund program has an impact on facilitating community mobility, improved irrigation channels that can increase crop yields, increase knowledge and create public awareness. Village fund has been able to reduce poverty, although allocation of village fund is used more for infrastructure development than for community empowerment. Through the Ministry of Finance Regulation number 93 / PMK.07 / 2015 concerning Procedures for Allocation, Distribution, Use, Monitoring, and Evaluation of the Allocation of Village Fund. The government is trying to make the mechanism for using village fund as simple as possible so that the community has no difficulty in receiving or using it and is responsible for it. The allocation of village fund is prioritized to finance the implementation of programs and activities in the field of village development and village community empowerment. The field of village development is procurement, development, and maintenance of basic infrastructure facilities for infrastructure needs, residential environment, transportation, energy and communication information, health infrastructure, education, and culture. However, if we look directly at the village there are still many obstacles encountered in realizing allocation of village fund, such as not in accordance with government regulations in their implementation, not involving the community in planning and human resources, which are not ready to receive allocation of village fund.

According to Sulila (2019), the Government is the highest authority in managing State finances as well as possible in order to achieve Good Government through policy implementation. Whereas Implementation according to Keban (2014) relates to various activities directed at the realization of the program. Therefore, Gorontalo District Government has sought to implement the Allocation of Village Fund Policy to all villages. The policy for allocating village fund in the Regency is based on the policy of the Regents of Gorontalo Regency Number 78 of 2017 concerning the procedure for allocating the Allocation of Village Fund originating from the 2018 APBD. Although it seems slow in responding to the Allocation of Village Fund policy that has been rolled out by the central government since 2006, the spirit of Gorontalo Regency to implement the Allocation of Village Fund is driven by the importance of the Village's position in regional development. The Allocation of Village Fund is the acquisition of a portion of the Village's finance from the Regency whose distribution is through the Village treasury and is part of the Central and Regional Financial Balance fund received by 
the Regency. The allocation of village fund is necessary because its policy is in line with the regional autonomy agenda, where the Village is placed as the basis of decentralization. The Policy is relevant to the perspective that places it as a basis for participation. The Allocation of Village Fund is intended to finance village government programs in terms of implementing government activities and community empowerment. The purpose of the Allocation of the Village Fund among others, is to improve the administration of the village government in carrying out government, development and community services in accordance with its authority. In addition, it is also intended to be able to improve the ability of community organizations in the Village in planning, implementing, controlling development in participation in accordance with the potential of the Village.

The allocation of village fund is expected to increase every year, bearing in mind the population also continues to increase. Based on data from the population in Gorontalo Regency (BPS, 2019) it has reached 388,821 people. In general, the composition of the population is balanced between male population and female population (sex ratio), a number of 193,413 women and male population reaching 195,408 inhabitants. The importance of allocating village fund to communities in Gorontalo regency in efforts to improve welfare has attracted the interest of researchers to carry out empirical studies in the field about the implementation of the allocation of village fund policies and the complexity of the problem. Based on the above documentation, this study focuses on the factors that determine the effectiveness of the implementation of village fund policies in Gorontalo Regency.

\section{METHOD}

This study used qualitative research methods. According to Moleong (2014), qualitative research methods intend to understand the phenomena experienced by research subjects, by describing them in the form of words and language, in a particular context is natural and by utilizing various natural methods. Based on the results of preliminary observations in the field and the complexity of the issue of village fund, the data collection was carried out through 1) Library research, namely research carried out by citing several kinds of literature and previous research results that have a relationship with the focus of village fund policy studies researched. 2) Field Research (Field Research), which consists of: a) Observation, i.e. observing and examining things and circumstances that have relevance to the research material. b). Interview, Namely conducting interviews with parties who are considered to have a strong relationship with the issues examined. c). Documentation, which is collecting data by compiling data and information needed in this study, especially those sourced from agencies that have something to do with this research. The interactive data analysis components used are, according to Miles, Huberman, \& Saldaña (2014), described as follows.

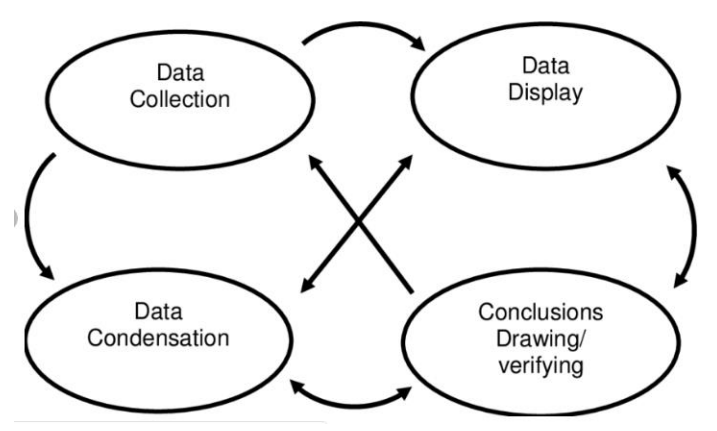


194 Jurnal Ilmiah Ilmu Administrasi Publik: Jurnal Pemikiran dan Penelitian Administrasi Publik

Volume 9 Number 2,July - December 2019. Page 191-202

Figure 1. Analysis componentInteractive Data Model

Based on the complexity of the problem and the method approach, the Types and Sources of Data used are: 1) Data Types. Qualitative data, namely descriptive data that is expected to explain the focus of the problem to be examined. The data can be in the form of various factors that determine the effectiveness of public policy implementation, including participatory, communication, resources, implementing attitudes, organizational structure, and environment. 2) Data Sources. The data used in this study were taken from key informant sources related to the realization of the allocation of village fund each year, per capita income, and various determinants of the effectiveness of the implementation of village fund allocation policies in Gorontalo Regency.

\section{RESULT AND DISCUSSION}

Gorontalo Regency was formed based on Law Number 29 of 1959 concerning the Establishment of Second Level Regions in Sulawesi with its original capital city, Isimu. In 1978 the Capital of Gorontalo Regency was moved to Limboto. Until 2019, Gorontalo Regency consists of 19 districts, with the population in the last five years can be seen in the following table.

\section{Table 1.}

Total Population Gorontalo Regency

\begin{tabular}{|l|l|r|c|}
\hline No & Year & \multicolumn{1}{l|}{$\begin{array}{l}\text { Total } \\
\text { Population }\end{array}$} & Explanation \\
\hline 1 & 2014 & 368.149 & - \\
\hline 2 & 2015 & 370.441 & - \\
\hline 3 & 2016 & 372.856 & - \\
\hline 4 & 2017 & 374.923 & - \\
\hline 5 & 2018 & 388.014 & - \\
\hline
\end{tabular}

Source: BPS Gorontalo Regency in 2019 
The table above the population in 2014 was 368,149 , in 2015 , the population increased to 370,441, in 2016 and 2017 there was an increase of 372,856, and 374,923, and in 2018 it became 388.014. As previously explained, the Allocation of Village Fund policy is based on Gorontalo District Regulation No. 78 of 2017 concerning the procedures for allocating Allocation of Village Fund originating from the 2018 APBD. Realization of the Use of Village Fund Allocation The use of Village Fund allocation was issued from 2014-2018. So the financing of government administration has been financed in the last 5 years, which originates from the Village Fund Allocation, which has helped the village government a lot. To find out how the Realization of Village Fund Allocation in Gorontalo Regency can be seen in the following table:

Table 2.

Realization of Village Fund Allocation Gorontalo Regency.

\begin{tabular}{|l|c|c|c|}
\hline No & Year & $\begin{array}{c}\text { Village Fund } \\
\text { (Rp.) }\end{array}$ & $\begin{array}{c}\text { Realization } \\
\text { (Rp.) }\end{array}$ \\
\hline 1 & 2014 & 19.302 .645 .000 & 19.302 .645 .000 \\
\hline 2 & 2015 & 63.458 .614 .796 & 63.458 .614 .796 \\
\hline 3 & 2016 & 67.478 .016 .196 & 67.478 .016 .196 \\
\hline 4 & 2017 & 68.325 .863 .000 & 68.325 .863 .000 \\
\hline 5 & 2018 & 66.660 .738 .600 & 66.660 .738 .600 \\
\hline
\end{tabular}

Source: Village Community Empowerment Agency Gorontalo Regency.

Based on the field studies, the results show that the GDP of Gorontalo Regency in the last 5 years is as follows: in 2014 it reached 7,939,141, in 2015 it reached 8,983,341, 2016 reached 9,993,983, in 2017: 10,886,346, and in 2018 it reached 11,835. 690.

Furthermore, to find out the income per capita is calculated based on the following formula:

$$
\text { GDP Per capita }=\frac{\text { GRDP Per year }}{\text { Total Population }}
$$

Data obtained in the field show that the implementation of the allocation of village fund policy has a real impact on the community by increasing per capita income each year, namely in 2014 reaching 21,565.02 then in 2015 it increased to 24,007.44 and in 2016 it increased to $26,804.59$ and then in 2017 increased to $29,045.61$ and in 2018 to $30.503,25$. Based on the study of various literature in general, there are several aspects that need to be considered in the implementation of the Village Fund Allocation policy, namely: 1) The existence of 8 Village Fund Allocation Objectives which, when concluded in general, the Village Fund Allocation aims to improve the development aspects of both physical and non-physical infrastructure in order to encourage the level of community participation for empowerment and improvement of their standard of living. 2) The principles and principles of Village Fund Allocation management are transparent, accountable, and participatory. This means that the Village Fund 
196|Jurnal Ilmiah Ilmu Administrasi Publik: Jurnal Pemikiran dan Penelitian Administrasi Publik

Volume 9 Number 2,July - December 2019. Page 191-202

Allocation must be managed by promoting openness, carried out responsibly, and must also involve the active participation of all local communities. 3) The Village Fund Allocation is an integral part of the Village budget and income (hereinafter referred to as APBDes) starting from the planning, implementation, accountability and reporting. 4) The use of Village Fund Allocation is set at $30 \%$ for Village apparatus and operational expenditure and $70 \%$ for community empowerment expenditure. 5) Although the accountability of Village Fund Allocation is integral to the APBDes, it is still necessary to report on activities financed from the Village Fund Allocation budget periodically, and the final results report on the use of Village Fund Allocation. This report is separated from the accountability of the APBDes, as a form of control and monitoring as well as evaluation material for regional governments. 6) For the fostering and supervision of the management of the Village Fund Allocation a Regency / City Facilitation Team and the District Assistant Team were formed with obligations according to their level and authority. Funding for the referred Team is budgeted in the APBD and is outside the Village Fund Allocation budget. The eight important points above are intended to ensure the effectiveness of the implementation of village fund policies in accordance with the needs of community priorities. This is as according to Purwanto \& Sulistiyastuti (2012) explains, the suitability of the program with the needs is one indicator to measure whether the various policies carried out or programs received by the community in accordance with their needs or not.

In an effort to achieve policy effectiveness requires a measure of the accuracy of expectations, accuracy of implementation and accuracy of results achieved. In the literature study found an explanation according to Warsono \& Ruksamin (2014), there are three obstacles in policy implementation, namely 1) low community education, 2) low managerial ability from villages and other supporting institutions, 3) failure of the mechanism of socialization. Based on the results of empirical studies in the field, there are six determinants in the effectiveness of the implementation of village fund policies in the Gorontalo Regency. The six factors are explained as follows.

\section{Participatory}

Participation is a form of active participation in a series of activities with established goals and targets. In the context of the allocation of village fund policy, participation from each part of the village is needed to realize village development in accordance with the needs of the village itself. Community participation is one of the factors that influence the success of rural development and development programs. The results of the field study indicate that efforts are needed in inviting and realizing community participation in village community empowerment programs in a sustainable manner. Community participation not only involves the community in making decisions in every development program but the community is also involved in identifying problems and potential that exist in the community. Without a tangible form of active community participation, every program in the allocation of village fund policy will not be effective. Whatever the form of participation aims to improve the ability of everyone involved directly or indirectly in development by involving them in decision making and subsequent activities. Village community participation in the allocation of village fund policy 
varies relatively in terms of their intensity and in terms of their forms. In terms of intensity there are those whose participation is very low, and some are very high. In addition, in terms of form there are those whose participation is in the form of thought and there are also those who participate in the form of active participation in each activity.

In relation to the participatory concept, Uphoff, Cohen, \& Goldsmith (1979) divided participation into several stages, as follows: a) The stage of decision making. This concept was realized through community participation in meetings. The decision making stage in question is the planning of activities. b) Implementation phase. This concept is the most important stage in development because the core of development is its implementation. Real manifestations of participation at this stage are classified into three, namely participation in the form of thought contributions, material contribution forms, and actions as program members. c) The stage of enjoying results. This concept can be used as an indicator of the success of community participation at the planning and implementation stages of the program. In addition, by looking at the position of the community as the subject of development, the higher the benefits of the program are felt, meaning that the program is successful on the target. d) Evaluation Phase. This concept is very important because community participation at this stage is feedback that can provide input for the improvement and sustainability of the program.

\section{Communication}

Communication is the process of interacting with the delivery of messages through mediators. The influence of communication factors on implementation is on the clarity and content of messages to be understood thoroughly by the recipient of the message or program. To elaborate on how this communication factor influences, the writer will look at it from various phenomena during field observations related to the process of implementing the Village Fund Allocation policy. a) The intensity of the Socialization of Village Fund Allocation Policy. Associated with the intensity of socialization between policy actors and policy actors obtained information that normatively the socialization activities have been running. However, there are some informants who want to increase the intensity of the socialization of the Village Fund Allocation policy. b) Clarity of Communication. All information regarding the implementation of the Village Fund Allocation has been clearly described in the technical manual. Most of the Village Fund Allocation implementers have enough experience in carrying out Village Fund Allocation activities, it's just that in administrative management it is sometimes still confusing. From this information, it can be interpreted that the implementers of the Village Fund Allocation have obtained a clear message regarding the Village Fund Allocation policy. c) Consistency of Message. All information has been conveyed clearly and considers no overlapping explanation by the District Team with existing provisions. All Village Fund Allocation policy information must refer to technical guidelines set by the Regional Head. It can be concluded that there has been a consistency of messages, meaning that there are no conflicting messages. 
198 Jurnal Ilmiah Ilmu Administrasi Publik: Jurnal Pemikiran dan Penelitian Administrasi Publik

Volume 9 Number 2,July - December 2019. Page 191-202

\section{Resources}

The ability and availability of resources are one of the determining factors in the implementation of the Village Fund Allocation policy in Gorontalo Regency. Information sourced from the informants has quite diverse responses. But in essence they agree on the need to increase resources, both human resources and others. 1) Human Resources Capability. In general, the condition of the HR implementation of Village Fund Allocation is still limited, thereby affecting the quality of the implementation of the Village Fund Allocation. Village Fund Allocation to achieve standards on time, on quality and on administration. In other words the implementers of the Village Fund Allocation policy are not in accordance with competency standards even though they have enough experience. 2) Supporting Facilities. Village Fund Allocation Policy Relating to supporting facilities. However good participation and communication, but if not supported by supporting facilities, the implementation of the program in the field will not be effective. Therefore, in the implementation of the village government, they should prepare various supporting facilities needed in the operation of village fund policies.

\section{Implementer's Attitude.}

The attitude of the executor who supports the implementation of the Village Fund Allocation is very influential on the quality of the implementation of the Village Fund Allocation policy in Gorontalo Regency. The extent of the influence of the attitude of the executor in the implementation of the Village Fund Allocation can be explained through information sourced from the informants. In this case the informants tend to have the same view, namely the attitude of the executor who supports the implementation of the Village Fund Allocation. a) Implementing Perception. Implementers of the Village Fund Allocation policy have very supportive perceptions and expect the Village Fund Allocation Fund to continue to be rolled out and even increased. b) Implementing Response. Implementing responses were quite diverse, not all village heads responded quickly to the Village Fund Allocation policy. This can be seen from the fact that there are still many villages that are slow to complete the Village Fund Allocation requirements. This information shows that not all implementers have a good response to the Village Fund Allocation policy, because they consider the Village Fund Allocation Fund has become a routine every year. c) Implementing Actions. Although there are still implementers of the Village Fund Allocation policy that is lacking in response, informants stated that the Village Fund Allocation implementer has made activities and follow up. The implementers have had a stage of program activities to create activities that support the operations of the Village Government and community empowerment and infrastructure development.

\section{Implementing Organizational Structure.}

Bureaucratic structure influences the smooth implementation of Village Fund Allocation in Gorontalo Regency. The extent of the influence of the organizational structure factors in implementing the Village Fund Allocation can be explained through information sourced from 
informants who have the same response. This can be seen from the existence of the organizational structure implementing the Village Fund Allocation policy. Nevertheless there needs to be a clear division of tasks from the implementers of the Village Fund Allocation. The results of the field study can be explained as follows: a) Formation of Organizational Structure. The formation of the organizational structure implementing the Village Fund Allocation has been carried out in each village. The organizational structure in the implementation of the Village Fund Allocation has been regulated in the Bupati technical guidelines. b) Distribution of Tasks. In terms of the division of tasks within the implementing organization, the informant provided almost the same explanation. The informant stated that the need for emphasis and division of tasks was clear and measurable. Thus it is expected that the work is not only dominated by certain people. c) Coordination of policy implementers. The village head has not been able to coordinate all stages and sequences of activities so that the government partners in the village and the apparatus do not know clearly what must be done in the implementation of the Village Fund Allocation. Normatively it can be understood that actually in the Village Fund Allocation technical guidelines the division of tasks has been arranged among the Village Fund Allocation implementers, however the coordination problem often does not work which can be caused by synergy and togetherness and communication between fellow implementers in the field.

\section{Environment.}

Community institutions have a large enough role in channeling aspirations in the implementation of the Village Fund Allocation in Gorontalo District. The extent of the influence of environmental factors in the implementation of the Village Fund Allocation. The results of the field study indicate a) Environmental capacity. The intended environmental capacity is related to the ability of village representative institutions and village community organizations to influence the Village Fund Allocation policy. Village representative institutions and Village Community Institutions have the capacity, namely the authority in the form of supervision by village representative institutions whereas social institutions will assist the Village Head in implementing the Village Fund Allocation activities program. b) Role Stability. Related to the stability of the role of village representative institutions and village social institutions in supporting the Village Fund Allocation policy. The results of the field study indicate that village representative institutions have supported the Village Fund Allocation policy by participating in overseeing the implementation of the Village Fund Allocation. However, village representative institutions have not carried out their duties to assist the Village Head in implementing the Village Fund Allocation to the maximum. c) Complexity. Regarding the issue of environmental complexity, that is how much is the intervention of the community and social institutions towards the implementation of the Village Fund Allocation policy. The results of the field study showed a similar view. The government together with village institutions should try to accommodate the various interests of the community component through the Village Fund Allocation policy. Therefore in the future, togetherness and synergy are needed and establishing priority programs between the village government, the community, and their partners in the implementation of the allocation of village fund policy. 
200 Jurnal Ilmiah Ilmu Administrasi Publik: Jurnal Pemikiran dan Penelitian Administrasi Publik Volume 9 Number 2,July - December 2019. Page 191-202

Based on the results of the field study and discussion, various determinants of the effectiveness of the implementation of the allocation of village fund policies in the Gorontalo Regency can be described as follows.

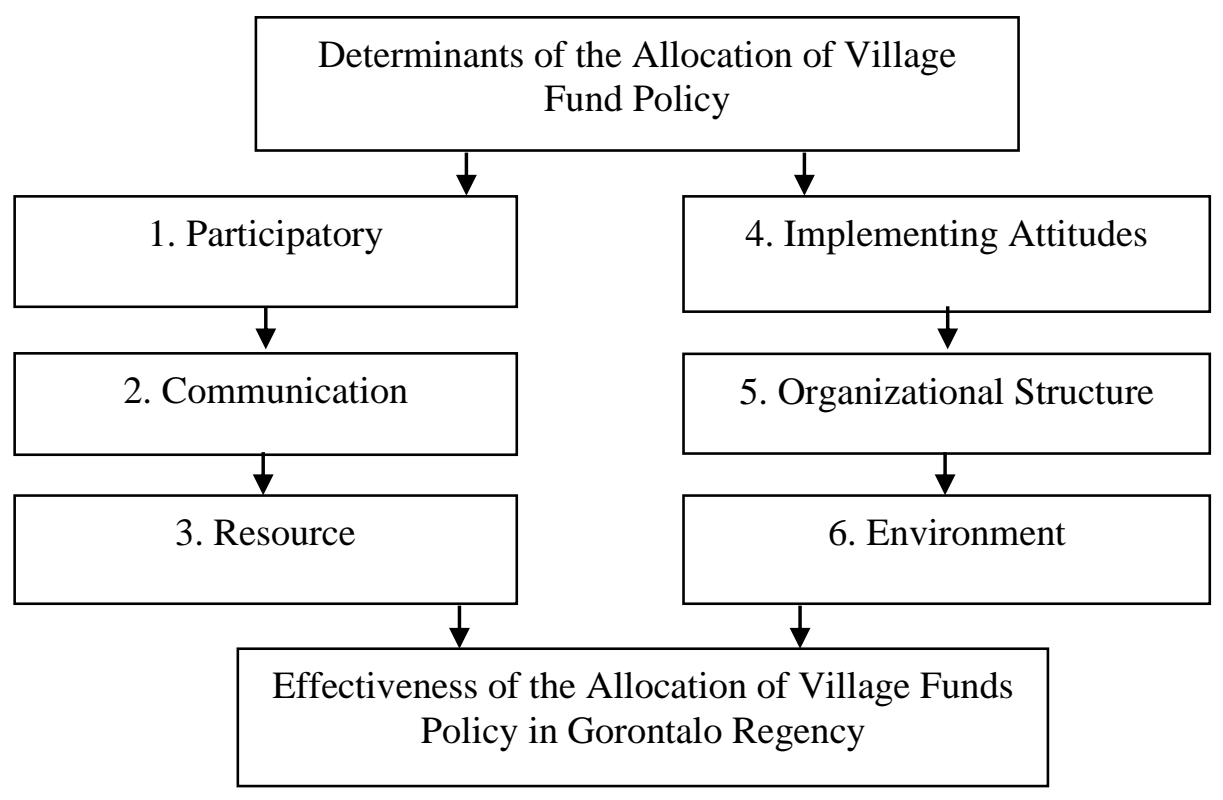

Figure 3.

Determinants of village fund policies in Gorontalo Regency

\section{CONCLUSION}

The results show that the realization of the allocation of village fund in Gorontalo Regency continued to increase. In 2014 the realization of 19.302.645.000, in 2015 the realization of 63.458.614.796, in 2016 the realization of 67.478.016.196, in 2017 the realization of 68.325.863.000 in 2018 the realization reached 66.660.738.600. The increase in the allocation of village fund has an impact on increasing income per capita every year. In 2014 it reached 21,565.02 then in 2015 it increased by 24,007.44, and in 2016 was 26,804.59 then 2017 increased by $29,045.61$ and in 2018 it became $30.503,25$. The results of empirical studies in the field show that there are five important factors that determine the effectiveness of the implementation of village fund policies in Gorontalo District, namely 1) Participation, 2) communication, 3) resources, 4) attitude of implementers 5) implementing organizational structure, 6) environment.

Based on the discussion and conclusions, it is suggested as follows: 1) to increase the realization of the allocation of village fund every year followed by the level of village development and increase in per capita income in a gradual, realistic, measurable and 
sustainable manner; 2) To be able to realize the real impact of the allocation of village fund, it should focus on various important aspects that determine the effectiveness of the implementation of the allocation of village fund policy as outlined in the research results and conclusions above.

\section{REFERENCES}

Abidin, M. Z. (2015). Tinjauan atas pelaksanaan keuangan desa dalam mendukung kebijakan dana desa. Jurnal Ekonomi Dan Kebijakan Publik, 6(1), 61-76.

Hehamahua, H. (2015). Impact Analysis of the Village Fund Allocation (ADD) Toward Economic Community (Case Study on the Rural District of Namlea Siahoni), Buru Regency. Journal of Social and Development Sciences, 6(3), 15-23.

Keban, Y. T. (2014). Enam Dimensi Strategis Administrasi Publik Edisi 3. Yogyakarta: Gava Media.

Miles, M. B., Huberman, A. M., \& Saldaña, J. (2014). Qualitative data analysis: A methods sourcebook. 3rd. Thousand Oaks, CA: Sage.

Moleong, J. (2014). Metodologi Penelitian kualitatif. Bandung: PT. Remaja Rosdakarya bandung.

Nawir, R., Maulana, R., Nuryamin, M., \& Husain, T. (2018). Implementation Program of Poor Rice Copyright. The International Conference On Social Sciences And Humanities 2018.

Prasetyo, Y., \& Masdjojo, G. N. (2015). Implementasi Kebijakan Alokasi Dana Desa di 10 Desa Wilayah Kecamatan Rembang Kabupaten Rembang.

Purwanto, A., \& Sulistiyastuti. (2012). Implementasi Kebijakan Publik: Konsep dan Aplikasinya di Indonesia. Yogyakarta: Gaya Media.

Sulila, I. (2019). The Effect of Human Resource Competency and Implementation of SIMDA on the Quality of Financial Statement at BPKAD Office of Gorontalo City. Publik (Jurnal Ilmu Administrasi), 8(1), 67-74.

Syamsiar, S., Saggaf, M. S., Salam, R., \& Ihsan, S. R. (2018). Implementation Of Supervision On Office Of Community Empowerment And Makassar City Village. The International Conference On Social Sciences And Humanities 2018.

Uphoff, N. T., Cohen, J. M., \& Goldsmith, A. A. (1979). Feasibility and application of rural development participation: a state-of-the-art paper.

Warsono, H., \& Ruksamin, D. (2014). The Obstacles of Implementation of Village Allocation Fund Program in the North Konawe Southeast Sulawesi. J. Mgmt. \& Sustainability, 4, 175. 
202 Jurnal Ilmiah Ilmu Administrasi Publik: Jurnal Pemikiran dan Penelitian Administrasi Publik Volume 9 Number 2,July - December 2019. Page 191-202 